\title{
THE DYNAMICS OF ASSOCIATIONS AND FOUNDATIONS IN ROMANIA. ECONOMETRIC ANALYSIS
}

\author{
Chelariu Gabriel \\ Alexandru loan Cuza University of lasi, Faculty of Economics and Business Administration, \\ lasi, Romania \\ chelariugabriel@yahoo.com
}

\begin{abstract}
This article highlights the evolutionary trend of the associations and foundations in Romania in 1997-2015 period of time. We know that the NPO's activities come to cover the people's needs which cannot be supported by the state or by the private sector. More precisely, the major roles of the NPO sector are: supporting disadvantaged groups and the social causes, sustaining the role of "watchdog", and promoting the advocacy and public policy expertise. For this reason, we propose an econometric model that will be applied to establish the link between the number of the association and foundations, poverty rate, unemployment rate and the average monthly expenditure per household. We consider that the last three factors are relevant to the country's social economy and, at the same time, they represent the main objectives of the EUROPE 2020 Strategy - a strategy for smart, sustainable and inclusive growth. The study is based on numerical data collected over a period of 12 years from 2003 to 2014. For the econometric model, we use IBM SPSS 22 software, in analyzing the collected data. After processing the data we will find a positive and significant relation between the number of associations and foundations (AF), the average monthly expenditure per household and the poverty rate. At the same time, we will find an insignificant relation between the number of associations and foundations and the unemployment rate.
\end{abstract}

Keywords: NPO, unemployment, poverty, expenditure per household, dynamic, econometric.

JEL classification: C22, C58, G01, M20.

\section{Introduction}

The evolution of the social economy has prompted the rethinking of the economic and social models in Europe, and has reinvented the social enterprises, forcing them to adapt to the new changes. This progress included transformations both in terms of the number of member organizations, which has grown significantly in the recent years, including a variety of areas, and in terms of the public and academic political debate (Barna, 2014:5).

For standing up, a civil society requires a healthy construction of the economy. Civil society is the "aggregate of non-governmental organizations and institutions that manifest interests and will of citizens" and also it refers to "individuals and organizations in a society which are independent of the government" (Dictionary.com's 21st Century Lexicon). "Civil society" refers to associational activities involving family, non-governmental organizations, pressure groups, charities, community groups, social movements and campaigning organizations. (Cohen and Arato, 1994; Keane, 1988). Civil society organizations can also play important roles in policy advocacy and in constraining state power in nontransitional states and countries where full democratization is unlikely (Alagappa, M., 2004:6). Furthermore, the civil society develops complementary activities in the state and not in opposition to it. In this context, the market economy can solve social problems requiring social cohesion and 
solidarity, and not least, sustain the civil society, but it is not enough. There is a clear need for the involvement of social organizations to sustain, voluntarely and financely of this endevour. Romania has joined other developed contries in this process of discovering, rethinking and developing the social economy, as evidenced by various organizations and covered areas, although the current dynamics of the sector and its size are not comparable with European countries (Barna, 2014:5).

The social economy appeared as a reaction of the civil society to the social and economic problems caused by contemporary economic and socio-political reality. For this reason, issues such as unemployment, education and well-being are the key points for the social economy (Giddens, 2000).

The concept of social economy designates the multitude of collective social-purposed initiatives that take place between the public and private business boundaries. The social goal of economic activities does not refer exclusively to the provision of social services, as the term could indicate, but refers to the social purpose of a variety of activities aimed at satisfying individual needs of mutual or general interest (Constantinescu, 2011:4).

The social economy has established itself as a mechanism of mutual assistance between different groups with similar activities, formed as cooperatives, or groups with similar needs such as mutual societies or mutual aid houses, and groups with similar aspirations, such as associations and foundations. These are, in fact, forms of manifestation of the social economy that have diversified over time and have taken significant dimensions across the community (Vîrjan, 2012:86).

CIRIEC defined the social economy as being "formed of private enterprises, formally organized, with decision-making autonomy and freedom of association, designed to meet the needs of members via the market, by producing goods and providing services, insurance and financing. Any distribution of profits or surpluses between members is not directly related to the capital contribution or contributions paid by members, each of them having one vote (CIRIEC, 2007:20)."

The concept of civil society refers to institutionalized or informal collective activities which have as main function representing and promoting the interests of members. The social economy approach only concerns institutionalized entities (with legal personality) and distinguishes between representation activities and those with a pronounced economic character, such as providing goods or services of mutual or general interest. In this context, the social economy is what could be called the economic sub-sector of the non-governmental or civil society sector (Constantinescu, 2011:7).

The non-profit organizations support their activity, on one hand, on voluntary and paid work, and on the other hand, on a combination of financial resources generated by selling goods and services, public funding and private donations. Thus, the non-profit organizations have a significant contribution to the social cohesion, innovative services sectors, but also in solving social problems affecting a large number of social categories (Cace, Nicolăescu, Anton and Rotaru, 2011:7).

This paper aims to conduct statistical and dynamic analysis of the social economy sector, focused on associations and foundations.

Organized in an autonomous form, in terms of decision-making and freedom of association, the associations and foundations are private entities created for providing free services for beneficiaries and whose surplus, if any, cannot be self-taken by those who create, control or finance them. The non-profit organizations meet the needs of an association in terms of self-management or autonomy in relation to public authorities, contributing to crystallizing and highlighting the civil society, providing, for the local and professional community, opportunities for offering services focused on public good (Badrus, 2001).

The non-profit organizations, mainly make their contribution in supporting the activities at local, regional or international levels. Internastionally known organizations have lobby power, and influence in the political or economic environment or at least they attract the attention 
and the public interest on some situations or projects. A local or regional level concerns primarily in supporting the local community, creating opportunities for strengthening community spirit or most often conducting charitable activities. Thus, an organization can perform various tasks and bring many benefits. Through the communication methods, the staff of such organizations manages to raise funds and to participate in various projects to gain various national and international financial resources. The funds are used to improve the services, to organize thematic competition and to create an appropriate communication environment, through the web and blog pages. (Cace, Nicolăescu, Anton and Rotaru, 2011:79).

\section{The dynamics of associations and foundations}

It is a known fact that, over time, the companies have been divided into two sectors, namely the private sector, represented by all companies and organizations carrying out activities to obtain profit, and the public sector, represented by the state bodies, which are organized and function for and on behalf of citizens. As time went on, along with the development of the modern society, the private sector began a reform splitting itself into two private sectors, differentiated by their purpose and by their intention of obtaining profit: the first sector whose activities are aimed to obtaining profit, and the second, aimed at obtaining resources which are later redistributed to the members of society. The latter has been called "the third sector" or "social economy" (Micșunica-Drețcanu and lorga, 2012).

The emergence of the non-profit sector supported the conclusion that neither the public, nor the private sector cannot cover all the needs that exist within society (Brinkerhoff and Brinkerhoff, 2002:4). Lately, it has been found that confidence in the government decresed more and more in terms of solving society's problems so there is a strengthening of the role of "the third sector" in the detriment of the two other sectors. This means that initiatives from citizens who are directly concerned, e.g. "bottom-up", are more effective in solving certain problems of the society, despite the public sector, and of the economy, leading to strengthening the influence of the citizens and civil sector.

The non-profit organizations are treated as non-governmental entities established "as a form of charity which doesn't seek profit for owners and whose principal purpose is the provision of public services or the defense of a cause. Therefore, they are considered to be private organizations, but aimed to fulfill public or quasipublic goals" (Vlăsceanu, 1996:19).

The NPOs can be defined as an intermediate structure, located between the public and the private sectors. They are designed to orientate their activity in a certain sense through interactions, horizontally, between the structures of the third sector, and vertically, with the institutions of the two other sectors, involved in solving society's problems. The Romanian economy needs a dynamic social economy, by linking the social and economic issues, by establishing public-private partnerships for the development and cohesion with the real economy. The main driver of the social economy is not the profit, but the action in the public service. Social enterprises achieve a surplus from the work they perform and, in addition to traditional private enterprises, support the growth of the area in which they operate.

The association is based on an agreement between three or more persons who have common knowledge, who input labor in the development of activities of general interest, in community, or, where appropriate, in the interests of their personal prerogatives. This establishment of the associations is made by the free expression of people that allow members to speak on matters of public interest or community members (Ordinance no. 26, 2000).

The foundation is formed by one or more persons who establish a patrimony which must include material goods or cash, whose value must be equal to 100 minimum wages. Its heritage is permanent and irrevocably meets an objective of general or community interest. (Ordinance no. 26, 2000). 
The fundamental difference between the two types of entities is that, while the association is a sum of wills oriented to achieving an objective, the foundation is an endowment oriented to achieving a goal, with all the consequences thereof, namely the existence of the members (if association) and different requirements for the establishment, required by government bodies. Moreover, there are specific requirments regarding management, and conditions of dissolution and liquidation.

Because of the social economy, at the national level, each type of organization may meet the growth trends and positive developments. For this to be feasible it must perfectly harmonize the important relationships of NPOs with all the means of the social economy sector.

Analyzing the situation in Romania, the specific activities involving NPOs are still shy, but there is a tendency of increased development and assimilation of concepts, strategies and processes undertaken by these organizations.

According to the National Statistics Institute, both associations and foundations have experienced significant growth during the 1997 - 2015 period of time, leading in 2014 to a total of 56.356 associations and foundations.

Analyzing annual records, a high level of registration of NPOs is shown in 2008. We note that after 2008 there was a decrease in the number of NPOs, but later it was restored and the sector continued to influence the social economy and meet the public support.

The following figure highlights the evolution of NPOs. The sharp decline observed in 2009, due to unfavorable economic conditions, was slightly oscillating, with a slight lag in 2010 as well, and then increased relatively slowly in 2011-2015.

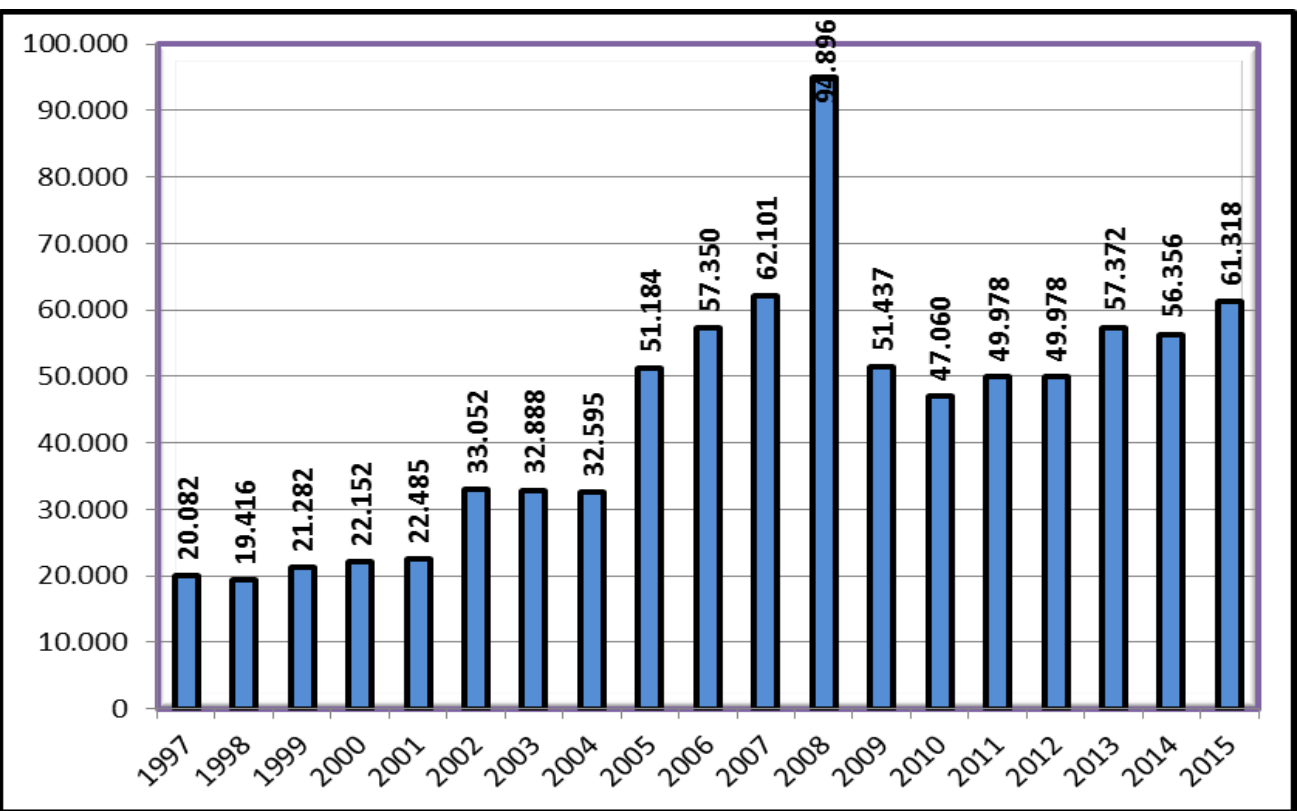

Figure 1: The increasing trend of associations (cultural and sport) and foundations in 1997-2015 period of time

Source: own processing based on data retrieved from NSI - National Institute of Statistics website

The NPO sector is mostly supported by donations, sponsorships, contributions and other non-profit revenues, but lately, their support is possible by developing economic activities which make possible the increase of their contribution to total revenue of the NPO's sector. For more than a third of NPO's, European funds or grants from international organizations are the most important sources of revenues (Lambru and Vameșu, 2010). 
The weaknesses of non-profit organizations that do not allow highlighting and developing a market, refer to the lack of cooperation between them, and to their individualism. Improving the communication between the different types of non-profit organizations and community-oriented partnerships, identifying community needs, developing projects designed to help local development, would bring an added value to the sector level and would enhance the credibility among community members.

The privations of the Romanian state are strongly felt at the level of the health system and at the social service level. This precarious situation, generated by the lack of interest, and investment in this direction, creates a favorable framework affirmation for the non-profit organization. The NPOs invested and helped identifying solutions, suitable to support areas such as health, social services, and the economic development. Although they cannot solve these problems in their entirety, the non-profit organizations are investing further in this direction, constantly adapting to the occurring changes in the social plan.

\section{Econometric analysis of the influence of Europe 2020 on the number of associations and foundations}

After the Second World War, a period of economic growth followed, with a focus on welfare, and so, the social economy had a very limited role on the market. In the last 20 years, the social economy has begun to gain contour and greater significance, due to the worsening social problems not only at European level, but at the global level: increasing unemployment rate, increasing poverty rate and social marginalization, increasing aging phenomenon of the population, reducing skills and social exclusion, etc. The welfare, which until then had the capacity and resources to provide adequate and diversified social services, has been suddenly confronted with a number of important challenges and overcome by the magnitude of economic and social events. All of these put a particular strain on statist social protection systems and, in this context, the social economy has become a solution for addressing social and even environmental issues (Vîrjan, 2012:86).

From the above figure, a positive trend in the number of associations and foundations from year to year can be seen, except 1998, 2000, 2004 and 2010 when they met a regression but not with high values. As stated above, the increase in the number of associations and foundations took place again from 2011. Starting from the idea that non-profit organizations are considered to cover the needs which neither the private sector nor the public sector can solve and the idea that social protection is found in the Europe 2020 strategy, the following working hypothesis was formulated:

H1: Increasing values of poverty, unemployment and population expenditure lead to an increase in the number of associations and foundations.

According to the above hypothesis, we have constructed the next economic model:

\section{Number AF $=f$ (Cost, Poverty, Unemployment)}

According to the above hypothesis, the economic model and the selection of measures for dependent and independent variables, our econometric model is:

Where,

$$
N_{t}=\beta_{0}+\beta_{1} C_{t}+\beta_{2} R_{s a r_{t}}+\beta_{3} R_{\text {som }_{t}}+u
$$

$\mathbf{N}_{\mathrm{t}}$ is number of associations and foundations

$c_{t}$ is average monthly expenditure per household in year $t$

$\mathbf{R}_{s_{s a r}}$ is the poverty rate in year $t$

$\mathrm{R}_{\mathrm{gom}}$ is unemployment rate in year $t$

$\mathrm{U}$ is error term or disturbance 
The constants $\beta_{0}, \beta_{1}, \beta_{2}, \beta_{3}$ are the parameters of the econometric model, and they describe the direction and the strengths of the relationship between number of associations and foundations and the factors used to determine number of associations and foundations in the model.

To obtain the data needed to construct the model, we used the statistic analysis published by the National Statistics Institute in conjunction with the Ministry of Justice, for the $2003-2014$ period of time. We mention that when writing this paper, the data for 2015 were unpublished.

Table 1: Dependent and independent variable values of the model

\begin{tabular}{|c|c|c|c|c|c|}
\hline Year & $\begin{array}{c}\text { AF annual } \\
\text { records }\end{array}$ & $\begin{array}{c}\text { AF } \\
\text { cumulative } \\
\text { records }\end{array}$ & $\begin{array}{c}\text { Poverty } \\
\text { rate }\end{array}$ & $\begin{array}{c}\text { Unemployment } \\
\text { rate }\end{array}$ & $\begin{array}{c}\text { Average monthly } \\
\text { expenditure per } \\
\text { household }\end{array}$ \\
\hline $\mathbf{2 0 0 3}$ & 2990 & 44878 & $17.30 \%$ & $7.40 \%$ & 781.45 \\
\hline $\mathbf{2 0 0 4}$ & 2823 & 47701 & $17.90 \%$ & $6.30 \%$ & 1049.94 \\
\hline $\mathbf{2 0 0 5}$ & 3432 & 51133 & $18.20 \%$ & $5.90 \%$ & 1149.33 \\
\hline $\mathbf{2 0 0 6}$ & 4132 & 55265 & $18.20 \%$ & $5.20 \%$ & 1304.66 \\
\hline $\mathbf{2 0 0 7}$ & 4297 & 59562 & $24.60 \%$ & $4.00 \%$ & 1541.96 \\
\hline $\mathbf{2 0 0 8}$ & 3360 & 62922 & $23.60 \%$ & $4.40 \%$ & 1915.19 \\
\hline $\mathbf{2 0 0 9}$ & 4354 & 67276 & $22.10 \%$ & $7.80 \%$ & 2047.33 \\
\hline $\mathbf{2 0 1 0}$ & 4664 & 71940 & $21.60 \%$ & $7.00 \%$ & 2062.95 \\
\hline $\mathbf{2 0 1 1}$ & 4934 & 76874 & $22.20 \%$ & $5.20 \%$ & 2183.76 \\
\hline $\mathbf{2 0 1 2}$ & 4881 & 81755 & $22.60 \%$ & $5.40 \%$ & 2244.47 \\
\hline $\mathbf{2 0 1 3}$ & 5103 & 86858 & $22.40 \%$ & $5.70 \%$ & 2317.40 \\
\hline $\mathbf{2 0 1 4}$ & 4774 & 91632 & $25.40 \%$ & $5.50 \%$ & 2269.25 \\
\hline
\end{tabular}

Source: NSI 2003-2014, Ministry of Justice; own processing

Given the fact that in our table both annual and cumulative records were presented, we choose to continue our analysis based on annual records, as dependent variable, because it reflects the real trend of the number of associations and foundations compared to the cumulative records which show an increasing trend despite the actual number of organizations that were established each year.

The first step in testing our model consisted in a statistical description of the selected indicators. For all these indicators number of cases are equal to twelve. The results provided by SPSS show that AF annual records occur between 2823 and 5103 with a standard deviation of 798,876 , the poverty rate is between $17.30 \%-25.40 \%$ with a standard deviation of $2.76651 \%$, the unemployment rate between $4.00 \%$ to $7.80 \%$ with a standard deviation of $1.14561 \%$ and average monthly household expenditure indicator was established a range between 781.45 and 2317.40 with a standard deviation from 544.9745.

Table 2: Descriptive statistics

\begin{tabular}{|l|c|c|c|c|c|}
\hline & N & Minimum & Maximum & Mean & Std. Deviation \\
\hline AF annual records & 12 & 2823 & 5103 & 4145.33 & 798.876 \\
\hline Poverty rate & 12 & $17.30 \%$ & $25.40 \%$ & $21.3417 \%$ & $2.76651 \%$ \\
\hline Unemployment rate & 12 & $4.00 \%$ & $7.80 \%$ & $5.8167 \%$ & $1.14561 \%$ \\
\hline $\begin{array}{l}\text { Average monthly expenditure per } \\
\text { household }\end{array}$ & 12 & 781.45 & 2317.40 & 1738.9742 & 544.97450 \\
\hline Valid N (listwise) & 12 & & & & \\
\hline
\end{tabular}

Source: own processing in SPSS 
In order to obtain first results, we used a quantitative analysis that has as dependent variable for our model which is annual records of associations and foundations.

Table 3 describes the Pearson correlation coefficient between the dependent variable (AF annual records) and independent variables (poverty rate, unemployment rate and average monthly expenditure per household).

Table 3: Correlations

\begin{tabular}{|c|c|c|c|c|c|}
\hline \multicolumn{2}{|c|}{} & $\begin{array}{c}\text { AF annual } \\
\text { records }\end{array}$ & $\mathbf{R}_{\text {sar }}$ & $\mathbf{R}_{\text {som }}$ & $\mathbf{C}_{\mathbf{t}}$ \\
\hline \multirow{3}{*}{$\begin{array}{c}\text { AF annual } \\
\text { records }\end{array}$} & Pearson Correlation & 1 & $.645^{*}$ &,- 175 & $.860^{* *}$ \\
\cline { 2 - 6 } & Sig. (2-tailed) & & .023 & .587 & .000 \\
\cline { 2 - 6 } & $N$ & 12 & 12 & 12 & 12 \\
\hline \multirow{3}{*}{$\mathbf{R}_{\text {sar }}$} & Pearson Correlation & .645 & 1 & -.463 & $.803^{* *}$ \\
\cline { 2 - 6 } & Sig. (2-tailed) & .023 & & .129 & .002 \\
\cline { 2 - 6 } & $N$ & 12 & 12 & 12 & 12 \\
\hline \multirow{3}{*}{$\mathbf{R}_{\text {som }}$} & Pearson Correlation & -.175 & -.463 & 1 & -.182 \\
\cline { 2 - 6 } & Sig. (2-tailed) & .587 & .129 & & .572 \\
\cline { 2 - 6 } & $N$ & 12 & 12 & 12 & 12 \\
\hline \multirow{3}{*}{$\mathbf{C}_{\mathbf{t}}$} & Pearson Correlation & .860 & .803 & -.182 & 1 \\
\cline { 2 - 6 } & Sig. (2-tailed) & .000 & .002 & .572 & \\
\cline { 2 - 6 } & $N$ & 12 & 12 & 12 & 12 \\
\hline
\end{tabular}

${ }^{*}$ Correlation is significant at the 0.05 level (2-tailed).

** Correlation is significant at the 0.01 level (2-tailed).

Source: own processing in SPSS

It can be seen that between the dependent variable and independent variable unemployment rate is not a direct connection, registering negative Pearson coefficient, and the significance is well above the accepted maximum of 0.05 (Sig. = 0.587 ). We believe that this is due to declining values of recorded unemployment rate. This is not because the employment rate in public and private companies in our country has increased, but due to the high values of the rate of people leaving the country, values which were published by INSSE for emigrants $(19,056$ people in 2013). On the other hand, between the dependent variable AF Records annual and independent variables poverty rate and average monthly expenditure per household is a direct and close relation. In the first case, the Pearson coefficient value is 0.645 at a significance level of Sig. $=0.023$, in the second case the Pearson coefficient $=$ $0.860 \mathrm{Sig} .=0$. This is due to the constant increase in average monthly expenditure per household levels, which were higher than income growth, which leads to an increase in the poverty rate in the population. The increasing poverty rate automatically leads to an increase of certain needs of the population that can no longer be covered by the private or the public secto. In this case, associations and foundations are intervening.

In order to obtain more relevant data regarding the degree of influence of the independent variables Poverty rate and Average monthly expenditure per household on the dependent variable $A F$ annual records, we used a regression test through $\mathrm{F}$ (Table 4). Through research we obtained an $F=8.007$ significant at Sig. $=0.009$ less than the maximum permitted threshold of 0.05 which allows us to say with a high confidence level that the records of associations and foundations is strongly influenced by changes in the level of Average monthly expenses household and Poverty rate. 
Table 4: ANOVA $^{a}$

\begin{tabular}{|c|c|c|c|c|c|c|}
\hline \multicolumn{2}{|c|}{ Model } & $\begin{array}{c}\text { Sum of } \\
\text { Squares }\end{array}$ & df & Mean Square & F & Sig. \\
\hline \multirow{2}{*}{1} & Regression & 5266263.662 & 3 & 1755421.221 & 8.007 & $.009^{b}$ \\
\cline { 2 - 7 } & Residual & 1753975.005 & 8 & 219246.876 & & \\
\cline { 2 - 7 } & Total & 7020238.667 & 11 & & & \\
\hline
\end{tabular}

a. Dependent Variable: AF Number

b. Predictors: (Constant), Average monthly expenditure per household, poverty rate Source: own processing in SPSS

The results from Table 5 - Coefficients, allow testing the regression model parameters utilizing Sig t. It can be seen that the parameter Average monthly expenditure per household, complies the condition Sig $t<0.05$. On the other hand, the Sig $t$ values for Constant and for the Poverty rate are higher than 0.05 in both cases. In conclusion, with a $95 \%$ probability, we consider that only the Average monthly expenditure per household parameter is statistically significant in the model.

Table 5: Coefficients ${ }^{\mathrm{a}}$

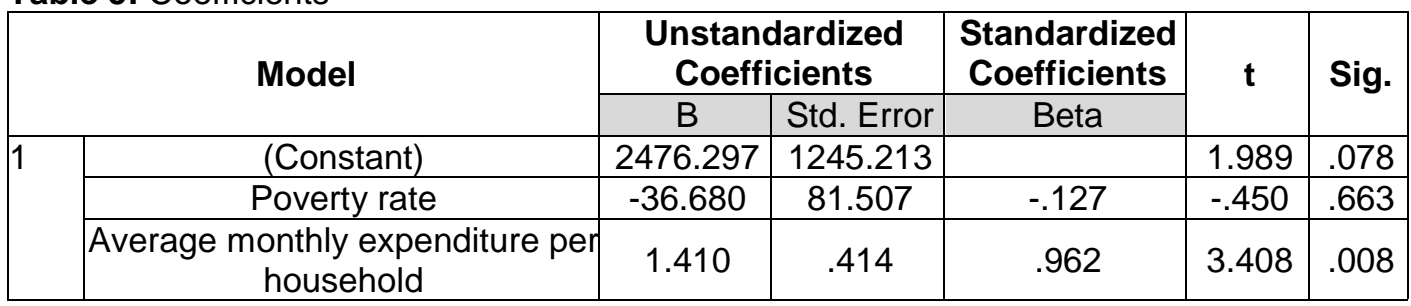

${ }^{a}$ Dependent Variable: AF annual records

Source: own processing in SPSS

\section{In conclusion}

The new social economy is emerging in the European Union as a pole of social utility in a pluralist economic system, alongside the public sector and the private for profit sector. Also it must meet the challenge of facing the dangers of dilution or vulgarization of its characteristics, which confer specific social utility.

To this end, social economy actors must better understand their common core values that make reference to the use of all the social and cultural levers, considering these values in order to reaffirm their own institutional profile and get a multiplier effect of their economic and social potential.

In this econometric study, we tried to analyze the influence of three factors: the average monthly expenditure per household, the unemployment rate and the poverty rate on the number of the associations and foundations in Romania. The necessary data for the 2003-2014 period of time were obtained from the website of the Ministry of Justice and from the National Institute of Statistics. After testing the econometric model, we discovered a direct and significant correlation between the dependent variable, the number of associations and foundations and the independent variables, the poverty rate and the average monthly expenditure per household. We have not found any connection between the dependent variable and the independent variable, the unemployment rate. In this case, to be used, the model can be rewritten either by removing the independent variable which does not have any influence, or by replacing it. Also, it is indicated to replace the poverty rate variable too, as the regression results show us. 
But there are other indicators that can help analyzing the dynamics of the number of associations and foundations. In our model, we were optimistic and we have started from the premise that associations and foundations are established to cover the needs that neither the state nor the private sector can cover. But it has been mentioned the fact that we cannot say, with a high degree of confidence, that all non-profit organizations are set up to support disadvantaged persons. For this reason, we believe that we should analyze the dynamics of the non-profit sector in terms of subsidies to this sector, of revenues received by it and in terms of average wage received by an employee from the non-profit sector.

\section{References}

Alagappa, M. (2004) Civil Society and Political Change in Asia: Expanding and Contracting Democratic Space. Stanford. Available at: papers2://publication/uuid/31A4D767-2DBF-47DA-8A47-450DBE784AA5.

Avila R.C. and Campos J. L. (2005) The social economy in the European Union, CIRIEC, Available

http://www.ciriec.ulg.ac.be/fr/telechargements/RESEARCH_REPORTS/EESC2007_\%20E ngli shReport.pdf.

Badrus, N. (2001) Societatea civilă în România după 1989. Geneză. Moduri de acțiune [Civil society in Romania after 1989. Genesis. Modes of action], Sibiu, „Lucian Blaga” University. Barna, C. (2014) Atlasul economiei sociale - România [The Atlas of Social Economy Romania], Bucharest.

Brinkerhoff, J. M. and Brinkerhoff, D. W. (2002) Government-non-profit relations in comparative perspective: evolution, themes and new directions. Public Admin., Dev., 22: 3-18. doi:10.1002/pad.202.

Cace, S., Nicolăescu, V., Anton, A.N., and Rotaru, S. (2011) Organizațiile neguvernamentale și economia socială [The nongovernmental organizations and the social economy], Bucharest, Expert.

Cohen, J. and Arato, A. (1994) Civil society and political theory. Cambridge, MA: MIT Press. Constantinescu, S. (2011) Atlasul economiei sociale - România 2011, Versiune preliminara [The Atlas of Social Economy - Romania 2011, Preliminary version ].

Giddens, A. (2000) The Third Way and its Critics, Polity Press, Cambridge.

International Centre of Research and Information on the Public, Social and Cooperative Economy (CIRIEC) (2007) The Social Economy in the European Union, Bruxelles, European Economic and Social Committee.

Keane, J. (1988) Civil society and the state: New European perspectives. London: University of Westminster Press.

Lambru, M. and Vameșu, A. (2010) România 2010. Sectorul neguvernamental - profil, tendinţe, provocări [Romania 2010. The non-governmental sector - profile, trends, challenges], București: Fundaţia pentru Dezvoltarea Societăţii Civile.

Micșunica-Drețcanu, D. and Iorga, E. (2012) Economia socială: al treilea sector Recomandări pentru buna funcționare a unei întreprinderi sociale în România [The social economy: the third sector - Recommendations for the functioning of a social enterprise in Romania], Bucharest, the Institute for Public Policy.

Vîrjan, D. (2012) Noi abordări ale economiei sociale [New Approaches to Social Economy], Economie teoretică şi aplicată, vol.XIX, no. 6(6), pp. 85-91.

Vlăsceanu, M. (1996) Sectorul non-profit. Contexte. Organizare. Conducere [Non-profit sector. Contexts. Organization. Lead], Bucharest, PaidefeCS.

www.mfinante.ro, [02 Dec 2016];

www.stiriong.ro, [23 Nov 2016];

www.http://data.gov.ro/dataset/registrul-national-ong, [23 Nov 2016]. 
*** Civil society. (n.d.). Dictionary.com's 21st Century Lexicon. Retrieved September 23, 2016 from Dictionary.com website http://www.dictionary.com/browse/civil-society;

${ }^{* * *}$ Ordinance no. 26 of 2000 on associations and foundations (published in the Official Gazette no. 39 dated 31 January 2000).

\section{Bio-note}

Gabriel Chelariu is PhD student in Accounting, "Alexandru loan Cuza" University, Faculty of Economics and Business Administration, Department of Accounting, Business Information Systems and Statistics. His areas of interest include fundamentals of accounting, financial accounting, non-profit organizations accounting. He published research papers regarding the accounting of non-profit organizations and participated in different national and international conferences. 